\title{
A Qualitative Insight into Gendered Vulnerabilities: A Case Study of the Shishper GLOF in Hunza Valley, Pakistan
}

\author{
Zainab Khalid ${ }^{1,2}\left(\mathbb{D}\right.$, Xing-Min Meng $\left.{ }^{3, *} \mathbb{(}\right)$ and Abda Khalid ${ }^{2}$ \\ 1 College of Earth and Environmental Sciences, Lanzhou University, Lanzhou 730000, China; \\ zainab17@lzu.edu.cn \\ 2 Department of Development Studies, COMSATS University Islamabad-Abbottabad Campus, \\ Abbottabad 22060, Pakistan; abda@cuiatd.edu.pk \\ 3 School of Earth Sciences, Lanzhou University, Lanzhou 730000, China \\ * Correspondence: xmmeng@lzu.edu.cn
}

check for updates

Citation: Khalid, Z.; Meng, X.-M.; Khalid, A. A Qualitative Insight into Gendered Vulnerabilities: A Case Study of the Shishper GLOF in Hunza Valley, Pakistan. Sustainability 2021, 13, 8798. https://doi.org/ $10.3390 /$ su13168798

Academic Editor: Ramon Flecha

Received: 6 July 2021

Accepted: 3 August 2021

Published: 6 August 2021

Publisher's Note: MDPI stays neutra with regard to jurisdictional claims in published maps and institutional affiliations.

Copyright: (c) 2021 by the authors. Licensee MDPI, Basel, Switzerland. This article is an open access article distributed under the terms and conditions of the Creative Commons Attribution (CC BY) license (https:// creativecommons.org/licenses/by/ $4.0 /)$.

\begin{abstract}
Gendered vulnerability from women's point of view has gained popularity in disaster studies in recent decades especially in the Global South. The positioning of women in society during normal times gives rise to vulnerabilities that are revealed when a disaster strikes. These vulnerabilities are often deep-rooted in societal makeup, cultural and traditional norms, and the economic fabric of society. In the context of Pakistan, the role of women in disaster risk reduction programs is still an under-researched area. In this paper, the gendered vulnerability progression in one of the mountain rural communities of Hassanabad in Hunza Valley (Northern Pakistan) is analyzed post-Shishper glacier lake outburst flood (GLOF) in 2019 and 2020. The study uses empirical qualitative data. Semi-structured interviews were conducted with men and women of different age groups within Hassanabad village. A thematic gendered analysis unveiled several interlinked social, economic, and institutional vulnerabilities. The gendered transitional phase of Hassanabad society positively indicates women's involvement in different spheres of life, including disaster management and mitigation. However, the lack of gender consideration on a formal institutional level exacerbates the gendered vulnerabilities in Hassanabad village. The case study of Hassanabad demonstrated that women not only have an awareness of hazards but are also willing to participate proactively in disaster mitigation activities. Therefore, to reduce community vulnerability and yield long-term positive outcomes of disaster management and mitigation strategies, women must be involved at the formal institutional levels.
\end{abstract}

Keywords: gendered mobility; women's vulnerability; Upper Indus Basin; risk perception; rural mountain communities

\section{Introduction}

Disasters occur as a result of interaction among natural hazards, the human population, and their environments. Factors such as environmental degradation, poor use of natural resources, unsustainable developmental practices, and population dynamics impact the vulnerability of people to natural hazards [1-3]. The communities with low coping capacity and high exposure are often more at risk and face difficulty recovering from a disaster [4]. Pakistan, like many other developing countries, has low levels of human development, high exposure to natural hazards, and a high gender gap, which results in the increased vulnerability of people [5-7]. The effects of climate change are especially evident in the northern region of Pakistan in the past few decades. The frequency and intensity of natural hazards occurrences has increased causing damage to life and property and putting the local communities at risk [8]. Although the climate-induced vulnerabilities affect both genders, these climatic shocks and extreme events affect men and women differently $[9,10]$. According to Anderson (2009), "Gendered dimensions refer to social and cultural characteristics of masculinity and femininity that result in different roles and 
responsibilities for men and women in society, divisions of labor in the formal and informal economic sectors, and unequal access to information and resources" [1]. The gendered vulnerabilities are different in every society because both men and women have socially fabricated roles and responsibilities [11]. More often, women are more vulnerable because they are less educated than men, they are denied property rights, and they have difficult access to financial credits besides suffering from factors such as inequality, limited income opportunities, less contribution in decision making and limited access to resources [11,12]. Gender inequality amongst other factors determines the inherent vulnerability of communities [13]. In Pakistan, gender dynamics are a complex social arrangement that has existed through centuries. The roles and responsibilities assigned to different groups enable the society to function in a particular manner. Men are mostly seen in leadership roles, whereas women are mostly seen at the secondary level in social, economic and political spheres. Women are also generally considered as both physically and emotionally weak in comparison to men [14]. However, the 2014 deadly floods in Pakistan are a good example of how people (not 'men') took extraordinary measures for the sake of survival; challenging the usual patterns of behavior [14]. The incorporation of women's perspectives in disaster narratives is an emerging research interest in Pakistan. In fact, the role of women in DRR is still insufficiently explored the literature regarding gendered power relations and dynamics in societies during disasters $[15,16]$. The gendered roles affect responses to disasters and require an understanding of how livelihoods and natural resources are sustained by men and women within a community. The exploration of gendered dynamics in terms of masculinity and femininity in a society is challenging because gender is not static, but rather changes depending on several social, economic, political and cultural factors. Therefore, their work, access to resources and information, and experiences of natural disasters are different from each other. Particularly, the contribution of rural women to economic development and their empowerment is hindered by a number of social, economic, and cultural constraints. During extreme climatic events, they are regarded as more marginalized and vulnerable because of poverty and food insecurity [17]. Anderson (2009) deemed that the gender roles in rural communities far easier to discern than urban areas. Ideally, this could be true, but given the constant urbanization of the rural areas, even those far off in remote geographical locations is somewhat causing the definite line of gender roles to become blurry.

This paper aims to explore the gendered vulnerabilities in rural mountain communities in a post extreme natural event scenario. The study probes into the socio- cultural, and institutional positioning and placement of women within communities and how it alters during potential disaster situations. The contextually relevant experiences and their subjectivity as empirical evidence (from field data) are used to explore the gendered vulnerabilities in the Hassanabad community who is living in a multi-hazard environment in Hunza Valley. The community experienced the first glacial lake outburst flood (GLOF) after the Shishper glacier in the Hunza Valley advanced and blocked the path of glacier melt water and created a glacial lake. The flood event provided an opportunity to study gendered vulnerability in the remote rural mountain community of Pakistan.

\section{Materials and Methods}

\subsection{The Case of Shishper Glacier}

The Shishper glacier or Hassanabad Glacier (36.50-36.480 N/74.570-74.610 E) originates at the confluence of Shishper and Mochowar Glaciers in Hunza Valley, Karakoram region. In 2017, the Shishper glacier was observed to expand, which blocked the flow of Hassanabad Nullah; a water tributary originating directly from glaciers and fed by glacier melt water. The Hassanabad nullah originated from Shishper and Mochowar glaciers $5 \mathrm{~km}$ north of Hassanabad. The blockage created a glacial lake behind Shishper glacier (Figure 1). 


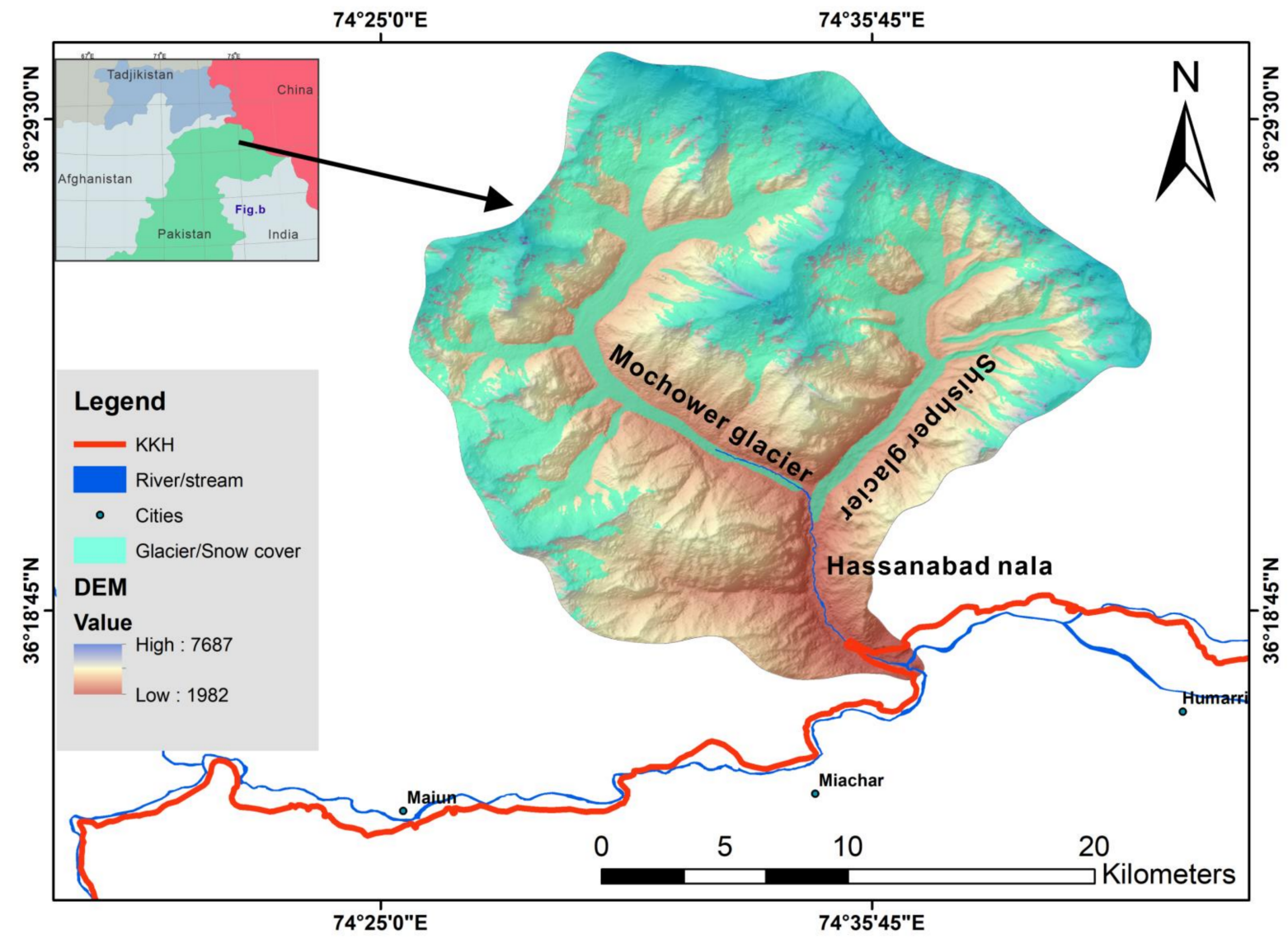

Figure 1. Study area map. (Source: authors' own 2021).

In 2019, the increasing water level in the lake threatened the downstream village of Hassanabad, which lies only $5 \mathrm{~km}$ from the glacier snout [18]. In addition to the houses and agricultural land, a hydropower station and a bridge of significant value were at risk (Figure 2). The District Disaster Management Authority (DDMA), Hunza, responded to the threat of flood by building a protective wall as a structural mitigation measure on one side of the river bank. The wall was built to keep the most threatened part of Hassanabad called Mohalla Sherabad (mohalla (urdu; singular) refers to a lane of houses located in close physical proximity) safe from the flood wave. The glacier lake burst occurred on the night of 22 June 2019, causing a flood discharge of 5000 cusecs water in the Hassanabad Nullah. The flood event lasted about 36 hours. The highly turbid flood wave carried eroded sediments, gravel, pieces of glacier ice, and small rocks with it. The protective wall was built to protect the communities from casualties and extensive infrastructural damage (Figure 3a). The only recorded damage was to an approximate $140 \mathrm{~m}$ segment of the Karakoram Highway (KKH) (Figure $3 \mathrm{~b}$ ) and the loss of a 70 sheep herd by a local farmer. After the GLOF event in 2019, no further mitigation measures (structural and non-structural) were adopted, and the communities remained exposed to possible future flooding events. On 28 May 2020, another glacial flood hit the Hassanabad nullah with water discharge around 2500-3000 cusec.

Although the 2020 flood was smaller than last year, it caused a significant amount of damage to the land and infrastructure in Hassanabad village, including the main bridge, agricultural land, houses, water channels, Jammat Khana (a multipurpose community center of the local Ismailia-Shia community) and a segment of the Karakoram Highway. Sixteen households that incurred physical damage (cracks) were evacuated and shifted to a temporary tent set up. 


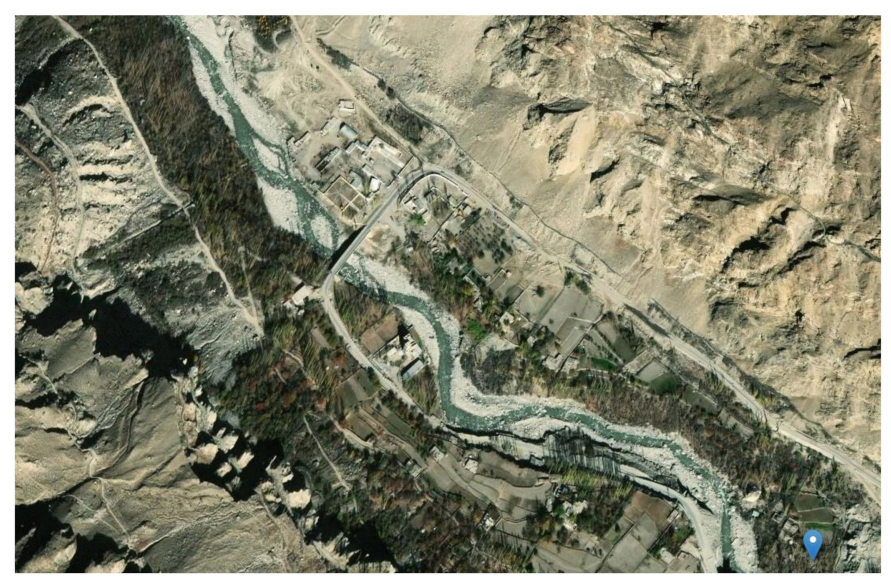

Figure 2. A CNS/Airbus image (15 May 2020), courtesy to Google Earth shows the valley of Hassanabad including the Hassanabad nullah, agricultural terraces, bridge and houses.
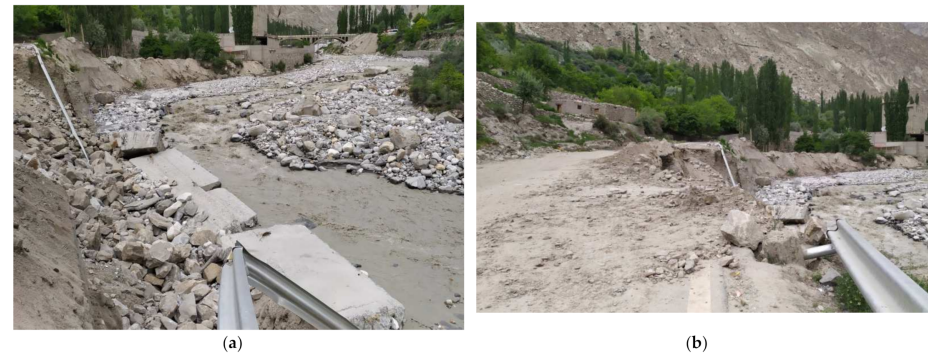

Figure 3. The aftermath of Shishper GLOF, 2019 The protective wall built by the DDMA is toppled over by the flood wave (a); The flood wave has destroyed a segment of Karakoram Highway disrupting the flow of traffic (b). (source: first author's fieldwork, 2019).

\subsection{Study Area}

For this single qualitative case study, fieldwork in Hassanabad village was conducted in 2019. Hassanabad is a small village settlement located in Hunza valley (360 $17^{\prime} 0.38^{\prime \prime} \mathrm{N}$, $\left.74035^{\prime} 35.10^{\prime \prime} \mathrm{E}\right)$. The Hassanabad watershed elevation ranges from 2000 to $7700 \mathrm{~m}$ above sea level [19]. In Hassanabad, natural hazards are not unknown to the local population. The glacier movements, glacial lakes, flood, landslide, rock fall, and debris flows are commonly experienced in the region. In fact, the movement of the Shishper Glacier is also not startling for the people (see Figure 4). However, there has not been an extreme event in their immediate vicinity in the last five decades.

The Hassanabad mountain settlement has around 175 houses sporadically built in pockets in the mountainous terrain. The Karakoram Highway traverses through the village. Clusters of houses on either side of the river as well as on top of the mountain (away from the river), are constructed depending on the availability of land (Figure 2). Hassanabad has three mohalley, namely Roshanabad, Sherabad, and Haarum. In this study, Roshanabad was excluded from the field because (a) the Shishper GLOF occurred during the fieldwork, which hindered the data collection process and limited the access to the population (b) Roshanabad was physically situated at a safe distance from Hassanabad nullah and was not threatened by Shishper GLOF.

The ratio of females is higher than males in Hassanabad village, approximately 52:48, respectively. The land distribution system in Hunza works along patriarchal lines [20]. However, over the period of time, due to the population growth and redistribution of landholdings among family members, several households do not own land anymore. Environmental hazards such as floods, river cutting and erosion have also contributed to the land reduction. Since the construction of the Karakoram Highway in 1978, the highly risk-prone mountain agricultural practices are continuously diminishing in the region as people gravitated towards high external income-generating options such as daily wage 
labor, labor migration, trade, and tourism, etc. [20,21]. In Hassanabad, many local men are employed at the Government Hydropower station, others work as daily wagers, and some have migrated to bigger cities for work. Women in Hassanabad on the other hand choose teaching as a career or have small home-based crafting businesses. A majority of the women take up the role of caregivers as housewives. On a small scale, the local people also indulge in fruit farming and cattle rearing. Although the literacy rate of women in Hassanabad is higher than downstream rural areas of Pakistan, there is a cultural marginalization of women that is addressed in the later section of the paper. The argument is specifically built around disaster planning and mitigation as it is the constant emerging threat in the region.

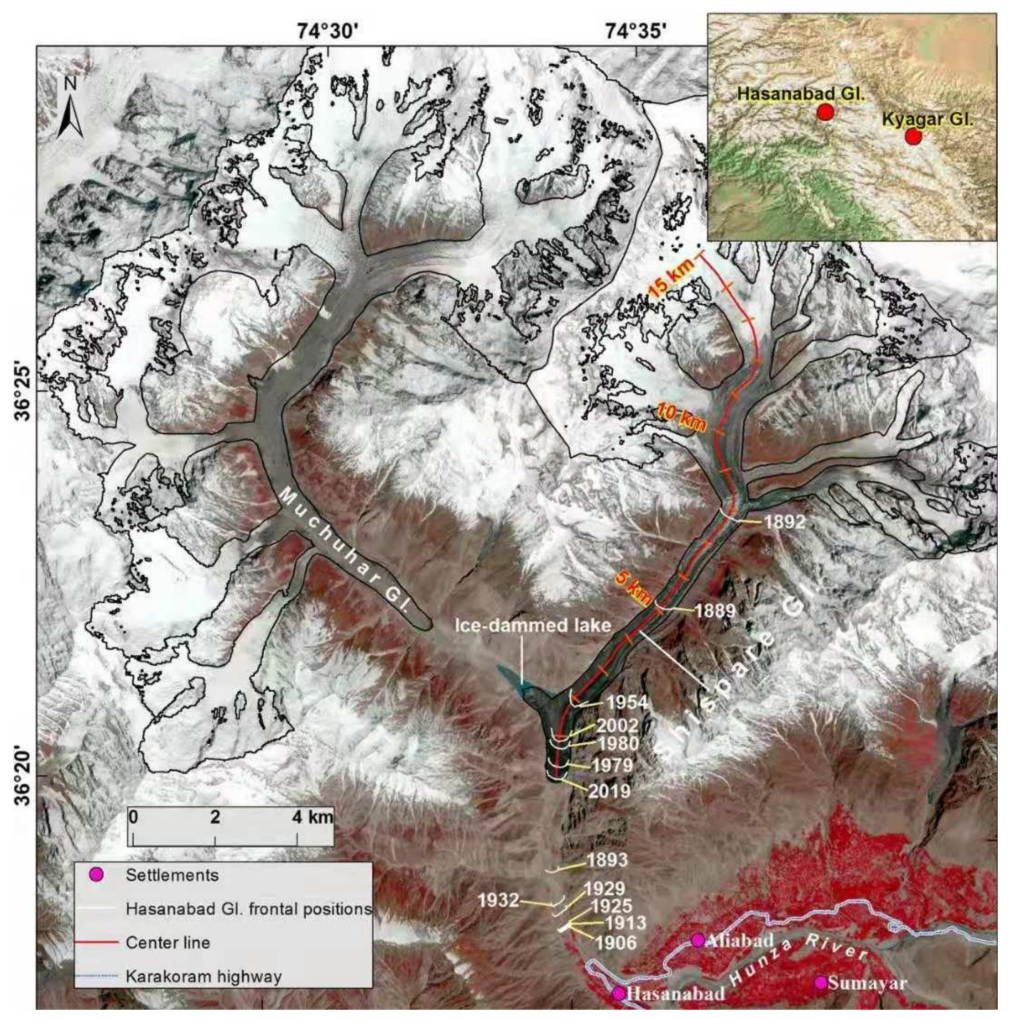

Figure 4. A map of Shishper Glacier with indication of surges throughout history (source: DDMA, Hunza, 2020).

\subsection{Data Collection}

For primary data, semi-structured interviews were conducted. Forty-one interviews were conducted with men and women from Hassanabad village using a random sampling technique. The interviews were mostly conducted in Urdu language. In some cases, for women who spoke Burushaski (the native language of people of Hunza), a local translator was hired who also acted as a guide to gain smooth access in the community, build trust with among people and remove any language barriers. For semi-structured interviews, a question guide was prepared in both English and Urdu languages. Numberdar (informal village head) and Mukhi (religious leader) were also interviewed to understand the sociocultural and economic dynamics of Hassanabad, especially in the context of growing hazard related vulnerabilities. Each interview was 40-60 min long. The interviews were tape-recorded (with permission) and later transcribed to be thematically analyzed. The economic stratification of households in Hassanabad (Table 1) shows that majority of the people belong to middle economic class. The difference in the economic status of the different households is reflected in their access to resources, which is discussed in detail later. 
Table 1. Economic stratification of the households in Hassanabad.

\begin{tabular}{cccc}
\hline & Economic Classes & Monthly Income & $\begin{array}{c}\text { Respective Percentage } \\
\text { of Household }\end{array}$ \\
\hline 1 & Poor & $10,000-19,000$ PKR & $15 \%$ \\
2 & Lower middle class & $20,000-39,000$ PKR & $34 \%$ \\
3 & Middle class & $40,000-60,000$ PKR & $37.5 \%$ \\
4 & Upper middle class & $>60,000$ PKR & $12.5 \%$ \\
\hline
\end{tabular}

Table 2 shows the demographics of the respondents. In addition to the semi-structured interviews, a focus group discussion of eight to ten females was conducted in Sherabad to understand women's perception of hazard, its impacts on their lives and livelihoods, and their knowledge and engagement in the Disaster Risk Reduction process. These women included the head of Tanzeem (Tanzeem is an economic intervention of Aga Khan Rural Development Program (AKRSP) for the empowerment of local women in the Ismailia-Shia community), wife of the Numberdar, wife of Mukhi of Sherabad Jammat Khana, members of a community volunteer group, wife of CERT Captain (Community Emergency Response Team or CERT deals with natural hazards and disaster management on informal communal level. The team works in close coordination with the NGO Aga Khan Agency for Habitat $(\mathrm{AKAH})$ ) and a few housewives. These women were chosen based on their involvement and engagement in community activities. However, the response of women was less engaging as more than half of the females walked out of the discussion after $40 \mathrm{~min}$. They had house chores and work commitments. Some women also expressed disinterest in the topic. The people (including women) in Hassanabad village attended several emergency trainings and drills over the years conducted by an NGO, Aga Khan Agency for Habitat (AKAH). As the flood did not cause any loss in terms of life and property, some women were not interested in talking about the event. The nature of discussifon was similar to the AKAH sessions, which some women found repetitive. Additionally, they claimed that their opinions/discussions do not influence the policy, planning and management; therefore, they prefer not to indulge in the focus group discussion. The attitude of women implied an undertheorized topic regarding intra-house gendered power imbalance and decision making. During crisis situations, the family dynamics play an important role in decision making as the spouses may not have the same opinions about disaster preparedness and mitigation [22,23]. However, the 40-min session was intense and women were quite vocal about their concerns. The one-to-one interviews with women, especially in mohalla Haarum of Hassanabad were most successful. The male residents of Hassanabad also had work commitments but participated in the interviews upon request. These interviews are quoted anonymously in the later parts of the paper accordingly with relevance to the subject.

Table 2. Demographics of respondents.

\begin{tabular}{|c|c|c|c|}
\hline Categories & Classes & Females & Male \\
\hline \multirow{4}{*}{ Age } & $15-20$ & 6 & 3 \\
\hline & $20-30$ & 4 & 4 \\
\hline & $30-40$ & 6 & 6 \\
\hline & $40-50+$ & 7 & 5 \\
\hline \multirow{4}{*}{ Education } & No formal education & 5 & - \\
\hline & Basic education & 5 & 2 \\
\hline & Secondary education & 10 & 11 \\
\hline & Higher education & 3 & 5 \\
\hline \multirow{4}{*}{ Marital Status } & Single & 7 & 5 \\
\hline & Married with no children & - & 2 \\
\hline & Married with children under 5 & 5 & 6 \\
\hline & Married with children older than 15 & 10 & 5 \\
\hline
\end{tabular}




\section{Results and Discussion}

According to Abbasi et al. (2019) in Hunza Valley, communities have a "genderegalitarian relationship," which allows women to have social capital, own businesses, jobs, and take part in commercial activities. Social capital is also the reason for the women to pursue high education, and therefore, they are not highly dependent on men and are less vulnerable in disaster situations than the women of rest of Pakistan. During the data collection process, it was found that women and men do not have a gender egalitarian relationship. In the literature, two distinct concepts conceptualize gender egalitarianism: (gender) equality in the public sphere or gender roles in the private sphere, particularly within homes. Gender egalitarianism also involves the relative positioning of men and women in public domains such as politics, education, and labor market [24]. Particularly in the context of disaster, there were several underlying factors related to women vulnerability which tacitly existed in the socio-cultural setting of Hunza Valley. Mulilis (1998) suggested that there is a difference in the engagement of males and females with hazard preparedness and mitigation activities, which could be due to the way they cognitively appraise the natural hazards and threats [25]. Here the thematic analysis of the Shishper flood event is conducted through the gendered lens to dissect the experiences of men and women. In addition, the analysis will also show how disasters impact the lives of men and women differently according to their social and economic positionality at the communal and household level.

\subsection{Gendered Perception of Hazard Risk and Vulnerability}

Perception is usually influenced by factors such as age, gender, income and education, past damages and experiences with hazards, and access to information [26-28]. Risk perception is used by the scientific community to measure public judgments, reactions, and acceptance of an event that drives human behaviors, decisions, and actions [29]. The qualitative results of the study showed that in Hassanabad, both men and women deemed disaster and the existing vulnerability as natural and believed that when a disaster strikes, everyone is equally affected. God saves or kills whomever He wants. In a society where religion is deeply seated, people's perceptions are usually intertwined. The interviewees demonstrated a rather complex and layered understanding of the environmental hazards. During the interview, the respondents did not separate their scientific knowledge, local knowledge and their religious beliefs. Their belief that God controls everything shaped up the general perception of people in terms of disaster and vulnerability. Interestingly, they also formed a correlation between climate change and extreme events which indicated their scientific understanding of natural hazards. However, for them there was still an element of 'naturalness' to the disasters. For the people the disasters were an "act of God," and they occurred upon God's will. Here it is important to note that language also influences the perceptions of local people. For example, the translation of "disaster" in Urdu is "qudarti (natural), aafat (disaster)," and "vulnerability" is "ghair mehfooz (unsafe)." If the disaster is conceived as a natural phenomenon, then the whole causal chain and resultant impacts are trivialized by different stakeholders, mainly decision-makers [30].

The discussion regarding men's and women's roles before and during natural hazard events, their strengths and weaknesses, the role of formal governmental institutions in disaster situations, and societal transformation in the recent decades helped the respondents to reflect deeper and focus more on their social positioning particularly from gender point of view. Three broad categories of perceptions emerged in the society as a result (i) men's perception of the vulnerability of women (ii) older women's perception of vulnerability of women (iii) young girls' perception of women's vulnerability.

Here, old indicates women above 40 , and young indicates women between 17-25 years. These two women age groups represent a generational gap which is reflected in their perceptions. The women between the age of $25-40$ had a blend of traditional and modern perception. The key differences between these categories are education and exposure. According to a report by ILO, the subordinate status of women in a society is the root cause 
of their vulnerability during disasters. The subordination is reflected in women's economic insecurity, sexual and domestic violence, care-giving responsibilities, and kinship relations, among others [31].

In Hassanabad, the vulnerability of women was associated with their physical attributes both by men and old women. According to both, the biological differentiation in the body functionality such as menstruation and pregnancy makes them more vulnerable. They argued that childbirth creates a deficiency of different vital components in women's bodies, making them physically weak. Women who are caretakers of their family and family-owned land and cattle also do not have access to resources and experience to utilize the resources, making them more vulnerable during the hazard events. The financial dependence creates a lack of confidence and dims the ability to make decisions during stressful conditions. It was very interesting that the women in Hassanabad were not strictly restricted to their homes. They were active members of the community and maintained social relations. However, despite this involvement, women felt that they are emotional, mentally, and physically not prepared for the highly distressful time of disaster. A statement by an old woman, a mother of six children, shows not only the level of physical vulnerability but also their perception of themselves as women.

"Women are sick, they have high blood pressure and old age. Who can run at this age or be so vigilant? Women are sick, weak, and not agile."

In the above statement, sickness, weakness, and agility could be analyzed as three separate issues in terms of physical sickness, emotional weakness, and lack of formal training. Although the emergency training sessions organized and conducted by AKAH are gender exclusive; women especially those who were old and stay at home mothers and caregivers did not feel confident that they were ready to face a hazard situation. The women however, agreed that if they were trained better and briefed properly about the situation, they could become emotionally strong during disaster situations. A married woman in her late twenties and mother of two children said,

"Women are emotional, and they are weak in decision making. During a disaster, like floods, some women cry over their land, their house, and other belongings in the house. They get emotional at that time. I think this is not right. Women must control their emotions, and they should help their male family members during this time. I do not know why women are overly attached to their houses and belongings. Everyone has a different perception."

The deep-rooted sense of helplessness among women in disaster-like situations developed a high level of dependency on men. The gender inequality in a society is often expressed through the lower status and power of women as compared to men. These power dynamics are addressed by feminist theories such as women in development (WID), women and development (WED), and gender and development (GAD). The dependency of Hassanabad women can be analyzed through the conceptual lens of 'power within' and 'power with' which refers to one's self-esteem and confidence and collective and organized power of a group with a unified goal [32].

The men in Hassanabad, on the other hand, accepted this dependency as a part of their social responsibility being males. One man narrated that during the flood; they were aware of every community member's health condition and were ready to take this responsibility of rescue and evacuation during the flood. The concept of 'power to' in this situation is extremely obvious because the men are quite easily stretching the limits of their boundaries to take on new roles and responsibilities without any resistance from women as an equal contender in this situation [33]. A man in his late 20s said:

"There was a sick lady in one of the houses. She could not move, so she said everyone else to go. We stayed in touch with her while keeping an eye on the water. We planned her evacuation among ourselves in case the water level crosses the threshold."

Within this context, we came across another woman, aged 32, who said 
"I think women cannot do anything unless men are not there for them. They cannot make any decision on their own; they are not as brain smart as men."

The above statement is an interesting reflection of women's perception of their vulnerability. Rowlands (1997) termed it as 'spiritual strength' which enables an individual to recognize the way their lives are operated by power and to harness that power to alter their conditions [34]. The low level of self-confidence in women shows that their vulnerability not only exists in the socio-economic and political context but is also present intangibly as part of their psychology and attitudes. During the data collection process, an interesting contradiction was found in the women of Hassanabad regarding their perceptions and actions. While they shared the stories of their inability to handle stress situation; their actions were simultaneously depicting another side. For example, a woman who is also a household head, decided to stay in their own house at the night of flood even though their house was very much vulnerable to flood due to physical proximity to the river. She said that she made a judgment call and stayed with the rest of the neighborhood even though she had rented a house in a safe location beforehand. Other instances are also highlighted later in the paper.

In this case, the contradiction could be attributed to of poor self-perception of women. The powerlessness expressed by women should be released through women empowerment interventions. The goal is to mobilize the resources such that the change comes from within and not from outside [34]. The results might progress the society into achieving a 'non-zero-sum power' state [33] where the power gained by women would not nullify the power held by men. Although the state of power equilibrium in a living society is idealistic, administrative regulation can at least ensure a near-equilibrium power state. In Hassanabad, AKAH has played a very active and positive role in women's empowerment through developing and enhancing their power within.

Women also stated that excessive responsibility for their homes, children, and property makes them physically and emotionally weak. They claimed that in the case of less burden, maybe they will be less vulnerable and would respond better during disaster situations. During the interviews with the male respondents, they were asked about the role of women during disasters. Their immediate response was, "women cry and weep during the disasters." The physical and emotional fragility of women served as a central debate for the majority of the respondents. They felt that in a crisis situation, women easily lose their nerves and most likely break down rather than becoming a proactive and responsible first responder. One man, aged 35, said:

"I think women are physically weak because of their responsibilities and bearing children. This is how the nature works. So, if in a situation where you can run and save your life, a woman might not be able to run well or in time or fast enough as compared to a man. If we look at this angle, then women are a little more vulnerable."

The young girls aged 17-25 in Hassanabad were mostly school and college students. There was a visible difference in their attitude, conduct, and confidence. The young women respondents had an altogether different perception about themselves and their role in disaster situations. They claim that their education has changed their perception of hazards and their role during such difficult times. During the Shishper glacier event, the young women were actively involved in the community-based flood water monitoring via community volunteer programs. The volunteers, both boys and girls, were on duty throughout the night. They monitored the flood water level and communicated the latest development to the households where women, children, old and sick were present. A 21-year-old female university student, said

"We believe we are equal to boys. It is about how one is trained. Our mothers and grandmothers never had the opportunity to do things independently, but we are a different generation. We are educated. We can understand any situation, make decisions, and act accordingly without much fear." 
In this regard, the male community members were noted to be accepting and welcoming of change with no apparent tug of power. Contrary to the differences in women perception, the responses of men from different age groups were quite alike. The similarity in the responses could be attributed to the dominant position of males in the society. Due to the patriarchal societal structure men often fail to acknowledge the underlying vulnerabilities of women. Their perception was based on the obvious societal developments and progress. For example, during the interviews, men admired the development and empowerment of women in Hunza Valley. Mukhi of Sherabad said:

"Women now days are more competent than men. If they are surpassing men in different fields, including disaster management, there is nothing wrong with it. If anything, we appreciate and encourage our daughters."

Older women also acknowledged that education provides opportunities to women such as confidence, knowledge and livelihoods that help them in decreasing their overall vulnerability. An old woman whose daughters are now college students said,

"Women who are educated have a better sense of the world. They are less vulnerable. They have the knowledge and education, and courage to face any unfavorable situation. The same is true for women who are financially independent. It is the uneducated, who face so many difficulties."

The results show that the perception regarding the gendered vulnerability of women is changing. Factors such as education, employment, mobility, and decision making combined with formal emergency trainings are decreasing the vulnerability of women.

\subsection{Gendered Access to Assets and Resources}

Assets and resources include both tangible and intangible resources such as information, decision making, and mobility, etc. In this study, three main assets and resources were identified namely information, communication, and post-disaster sanitation situation. The societal layout prior to any hazard event determines the access of women to these assets and the level of vulnerability it will likely produce. Bradshaw and Fordham (2013) wrote that the global situation of women's access to resources (in comparison to men) is poor, including income, education, health, and social networks [35]. We are taking the liberty to address some of these resources (such as health, sanitation, and education) under other themes as they signify other important disaster-related aspects of societal fabric.

The literature shows that women are more likely to seek disaster related information, take precautionary measures and prepare for emergencies than men [23]. In Hassanabad, women were very vocal about the hindrances they faced during the Shishper flood event. Women primarily based their social and climatic knowledge on their lived experiences and their ancestral knowledge [36]. As the Shishper glacier surge in 2017, women received glacier-related information indirectly via their male family members, informal meetings among women in the neighborhood where they exchanged information, online social networks such as Facebook and WhatsApp or through Jammat Khana. There is a wide spread use of smart phone technology in Hassanabad especially among the youth. The women who were less technologically savvy preferred to use simple mobile phones, however almost every household had smart phone users. We will analyze all three sources, one by one. The interviews of women showed that they strived to achieve a complex balance between their desire for more involvement and direct access to information and their trust in the most common information mediums that are their male family members and Jammat Khana. The women acknowledged that the information they receive was filtered as the male family members chose to re-tell the information they deemed important. A housewife, 50 , whose sons have a dry fruit market in the central village of Aliabad, said

"My son goes to the shop [in bazaar], meets other people, and we have a discussion later. We [women] stay home all day that's why we have less information. It would be really good, if I get the information and updates directly but my brother-in-law works with AKAH as a part of the community emergency team. 
During the Shishper event, he took pictures of the site and showed me on his laptop. I am satisfied with the information I get."

Ikeda (1995) argued that the social isolation of women during normal times restricts women from acquiring relevant and necessary information on risk minimization [37]. The theoretical debate of gender and public / private sphere, i.e., "The public sphere as male and the private sphere as female," dictates the social situation in our case study as well. Marshall and Anderson (1994) stated that the gendered segregation of public and private spheres has its roots first in patriarchy and later in capitalism [38]; however, we argue that in Hunza Valley, further amalgamation of cultural and religious connotation made it quite a complex system. In Hassanabad, women considered the indirect information reception as a viable method because they wanted to show their trust in the male family members. Most of the time, women tend to agree with the information they receive. The women in Hassanabad were also unable to participate in hazard and risk related discussion due to a lack of proper knowledge and in-depth information. Men, on the other hand, were not bound by any customary practices and mobility restriction; therefore, they had direct access to multiple sources of information. A majority of the men from Hassanabad conducted personal site visits to Shishper glacier to assess its behavior and flow of water. They also held numerous informal communal meetings, and attended formal meetings with District Administration, District Disaster Risk Management and Aga Khan Agency for Habitat (AKAH). A man in his late twenties told me:

"Most of the time, we try to keep ourselves updated by visiting the glaciers and observing whether it has surged or remained the same. This is a weekly visit. We also keep an eye on the weather forecast."

A community disaster committee was also formed on the village level, which constituted village notables, including Numberdar and other senior men. There were no women members of the committee. The all-males committee organized several meetings with the district government and other high officials such as Director-General Gilgit Baltistan Disaster Management Authority (GBDMA), Governor of Gilgit Baltistan, and Commander-in-Chief Pakistan Army. During the meetings, the village committee put forth their concerns, but due to the lack of women representation, there was no discussion on women's needs during the Shishper glacier crisis.

During the interviews, men were open to admit that women face difficulty in getting disaster-related information because of their restricted mobility and limited access to resources than women themselves. The Mukhi of Sherabad mohalla said.

"Women are usually the last ones to receive information; they probably miss out on [at least] some information."

During the study, it was analyzed that the role of Jammat Khana was very crucial in the hazard-risk-community vulnerability nexus as it was an efficient medium of information dissemination. The circulars from AKAH containing hazard updates and necessary precautionary measures were sent to each Jammat Khana, where all the attendees (both women and men) could access it firsthand. This practice was a positive step in bridging the gendered access to information. A young married woman said

"AKAH sends circulars and it is read aloud (usually on loudspeakers) from Jammat Khana. They inform us whether there will be heavy rainfall, snow avalanche, rock fall or heat stroke in the coming days. They also give precautionary steps like stock food, or do not travel, etc. with these weather updates. The warnings give us enough time to prepare ourselves for any situation. AKAH also gives us disaster trainings. I think these steps make the communities resilient and strong in their adaptive capacities."

AKAH has been working on building community resilience using non-structural measures such as verbal lectures, practical emergency drill, and first aid trainings for several years. These trainings are arranged in the Jammat Khana, where all men and 
women can easily attend. Data revealed that the number of women in emergency trainings was usually higher than men; however, women faced certain issues that hindered their learning. The dominating presence of men in trainings, both as trainers and participants, usually put women in the background. Many women claimed to feel 'shy', 'uncomfortable' and 'hesitant' to openly participate in trainings and drills. They admitted that during trainings, if they had a query, they chose not to ask in front of many people, especially men.

Access to Sanitation and Women Vulnerability

The third prominent area of concern was the gendered sanitation post-disaster. The women of Hassanabad have had a prior experience of living in the tent set up post a landslide induced evacuation. The tents were set where the evacuated families stayed for up to three months. Women and young girls alike reflected on the uncomfortable sanitation situation. The privacy for women was the main challenge as the facility was shared. Women were culturally and socially not accustomed to open deification, whereas men were not that strictly bound by cultural or social norms in this aspect. Women from all age groups with menstrual conditions found the tent set up to be a very uncomfortable experience especially because open discussions about menstruation are still considered a taboo in the society. In Hunza, women personally disposed of their sanitary material, and it is considered extremely unethical to throw them away with the regular waste. Such customary practices made it even more troublesome for the women to adjust to the tent setup.

One older woman in her late fifties explained it in detail

"For men, it does not matter where they live or stay, but for women, it is a problem, especially sanitation and other basic necessities. When you live in tent, men can go anywhere to wash themselves but women have restrictions. We have special needs for washroom and hygiene. There was no arrangement for women sanitation in the tent."

During the temporary stay in tents, women were forced to come back to their homes which were physically vulnerable to a landslide only to use washrooms. Although their homes were not declared safe from the threat of landslide and this unofficial arrangement put their lives at risk, the women deemed it to be most suitable.

They added that the government monitoring team was only men, and therefore, women did not feel comfortable sharing these private issues. Women explained how menstruation and other sanitation issue are private matters, and they cannot bring them up in any forum where the recipients/conductors are males. A middle-aged housewife said

"Whenever there is a disaster warning, we make sure that we keep our personal hygienic things packed, but usually, the disaster warnings are without a timeline. It creates an issue because we do not know for how long we will need to be out of our homes."

\subsection{Hazard Vulnerability and Gendered Division of Labor}

"The roles that people have within the family unit play a major part in what family members do, how they behave and respond during a crisis" [22]. The rural areas of Pakistan in general and the mountain region, in particular, have been agrarian, especially from the female employment point of view. Women's engagement in agriculture depends on a multitude of factors, including socio-cultural norms, agro-ecological conditions, and migration patterns [10]. Women are not only responsible for house chores and meeting the immediate survival needs of family members but also have to play a paramount role in agricultural activities and cattle rearing [39]. As their contribution is often in the form of unpaid labor, it is not as actively acknowledged in society. In disaster situations, the work carried out by women increases manifold, which directly impacts their vulnerability. Out-migration by male members of the families, especially off-farm seasonal migration, is a livelihood diversification strategy that is very common in Karakoram Region. They 
usually move to downstream urban areas or foreign countries. In Hassanabad, there were some families where males had migrated. Women who were left behind took charge of the household, cattle, and agricultural land. However, as access to resources differs for men and women, often times, women made decisions that suit them better, such as changing cropping patterns to reduce the risk of crop failure, etc. An old man, aged 55, said

"In the old days, women used to stay at home mostly, and men dealt with outside business. The decisions were made by men, and women agreed to them, but now things have changed. If you look at different communities in Hunza, you will see men and women work side by side and with cooperation. It makes the work easier for both of them."

In the above statement, the claim that the men and women 'work side by side' does not mean equal division of labor or equity of labor. In Hassanabad, the mobility of men revolved around resource procurement and management, while women remain at homes, with a more prominent role in the care economy, taking care of homes, children, and managing natural resources around the homestead. Thus, the gender division of labor was quite noticeable. A woman whose husband works in Karachi said

"There are some households where men have migrated for earning. They send remittances to their families. In such cases, women become the house heads. Women make daily life decisions, but they have to keep their husbands in the loop and cannot take a decision independently without informing their husbands. Decisions are made with mutual consent. Other times men are informed, and they take care of issues over the phone by getting in touch with other men in the village/ locality. It includes issues related to land, such as what to grow on land, land rental, hiring labors for land preparing, etc. They send money accordingly then."

Another woman's perspective of male migration was interesting and reflected diligently on how women perceived themselves in society. The quote below shows the strength and wisdom of women that they gain by being at the social and economic forefront. During the fieldwork, it was noticed that women rarely exhibited these qualities and usually felt comfortable behind the passive, submissive facade. This behavior was more prominent in married women as compared to unmarried girls. The unmarried girls were unhesitant to showcase their confidence and understanding of the gendered dynamics of labor in their society.

"I do not think that households, where men have migrated, are more vulnerable.

Women can take care of the house. Sometimes, the men are careless by nature; my own husband is like that. They do not look after the children, nor do they pay much attention to the land. In such situations, a woman becomes stronger because she takes care of land, house, and children. It is also training. If a woman does not have so many responsibilities, she will be less vulnerable in a disaster situation. Women have to worry about too many things as compared to men."

The above statement is from a local housewife which resonates very well with the literature where several studies have concluded that females are disadvantaged because of their domestic and agricultural responsibilities. It also shows that women take disaster risks more serious and threatening as compared to men [25]. The female-dominated agriculture sector leaves the women responsible for almost all the farming and non-farming responsibilities of their respective households. The feminization of labor in rural households of the Karakoram region places women in a vulnerable position. During most disasters, women face an immense amount of stress being the caregiver of their families and responsible for unpaid work for households [40]. This reality highlights the role and position of women at the forefront of mitigation and adaptation activities amidst differential access to resources, ownership, and control over critical natural resources [10]. In Hassanabad village, it was found that although women engaged in disaster preparedness, mitigation, response, and 
rehabilitation strategies, their responsibilities were focused on homes and families such as managing immediate resources like water and energy, preparation and provision of food, taking care of material items, keeping the house items or family possessions safe, looking after children and other family members. During flood preparation, women ensured that the important documents (degrees, property and bank documents, national identity cards, etc.) were sent to a safe location, usually a relative's place. Flood preparations also included stocking up on essential items in advance such as rice, flour, oil, dry fruits, and essential medication. During crises, people temporarily migrate to safe locations, taking their belongings and animals [41]. During the Shishper flood, the female-headed houses exhibited such proactive behavior more than the male-headed households. One female head rented a house in Aliabad a month prior to the flood and shifted her important furniture and possessions because her house was physically vulnerable to the flood. Another woman also said that her family rented a house in Aliabad at the beginning of 2019 and also shifted. However, when there was no flood until June, she shifted back as the rent was putting an extra financial burden on her family. She said that the responsibility of taking care of family, land, cattle, house, and other possessions are extremely unnerving for her. She claimed that had it not been for these responsibilities, women might not be so vulnerable during disasters. She further said:

"Women spend their life building these houses and filling them with furniture and other things. It is challenging for us to leave everything and go. No matter how tough the situation is, we always want to stay till the last moment to make sure that our belongings are fine."

The behavioral differences between men and women indicate that women are generally more inclined to participate in housebound disaster preparedness and mitigation activities than men [25]. However in households, typically natural hazard preparedness and subsequent decision making is performed jointly by the spouses [42], however there is a chance of incomplete or inaccurate information regarding household hazard preparedness if the spouses do not agree or communicate [23]. In both the cases stated above, women took excessive pressure onto them and took the precautionary measure to safeguard their house as well as their belongings. However, their decision to stay close to their own homes during flood also showed their care and emotional attachment to their economic assets.

\subsection{Unequal Women Representation in Formal and Informal Institutions}

In every society, institutions play a significant role in shaping economic activities, which leads to the speculation that these same institutions should also have a more prominent role in disaster prevention and management [43]. The government of Pakistan has numerous programs that facilitate climate change adaptation and disaster risk reduction. However, unfortunately, gender component in these programs lacks serious consideration. In Hassanabad, there are several formal and informal institutions. The lack of women representation at formal institutions such as District Administration, Hunza, and District Disaster Management Authority was obvious. There are no female employees in the whole Disaster Management Department neither at the district level nor at the provincial level. The gender imbalance at the institutional level is also reflected in disaster planning, and mitigation activities carried out by the district disaster management authority.

The women of Hassanabad village were very open in critiquing the established formal institutional setup, which neglects women's needs, especially during different phases of disaster. Although, theoretically, both men and women are free to approach the government institutions, however, there are invisible lines dictated by cultural practices and social structures that prevent women to freely access government institutions. In Pakistan, the institutional structures and processes remain patriarchal and largely male-dominated, making women uncomfortable [10]. The structural disaster mitigation planning by the Disaster Management Authority (Hunza) during the Shishper glacial floods was much appreciated by men, but the women pointed out their invisibility in both planning and execution phases. It shows that on the formal institutional level, the gender aspect is visibly 
ignored. Studies indicate that if gender is not considered during disaster relief programmes; women might become invisible in the process [44]. The gender inequality between men and women was already evident as men not only received more resources but also had more participation in the disaster planning and implementation phases. A young woman who had children under the age of five said:

"If the government would arrange disaster-related trainings specifically for women, tell them about safety parameters/measures and give them helpline numbers that would be very good. Here men are on the front foot and women are not given much attention. Men are in charge and they are included in all the tasks. I feel women should also be given some attention with regard to disaster management and training."

ILO (2002) argued that despite having indigenous knowledge, social networks, a strong position in families, and active role in outdoor work, women are not considered as 'front-line' responders during crises [31]. In Hassanabad, it was found that disaster-related trainings have had a profound positive impact on women's understanding and perception of disasters. The young educated girls were found to be vocal and confident. For them, the hazards were not merely 'acts of God' and 'guaranteed disasters-rather, they focused on the technical understanding of hazards and how they can be safe. A young girl, who goes to university in Lahore, said

"Education plays a vital role in determining the vulnerability of women. An educated girl is sensible and understands a situation in-depth, rather than taking things superficially or only at their face value. Like in this recent flooding event, the women were very much ready to take care of children and elders. The girls were on flood monitoring duty with the boys, they were actively going into homes to tell the people flood situation. Looking at that, I feel that girls are equal to boys. It is true that education enables women to act better, and educated women consider themselves safer than those who are not educated."

The above statement reflects how education is playing a vital role in changing the narrative around women's vulnerability and is gradually reducing the gender vulnerability gap. The data showed that education did not only empower women in terms of economic opportunities but also boosted their self confidence. During the interviews, the young women in Hassanabad clearlt stated that they are less vulnerable to the hazards as compared to their mothers ot grand mothers. The girls highlighted that due to their education, they are not only able to face unfavorable situatiions with confidence but also have the ability to take timely decisions.

The women above 40 years generally had no formal education. Despite that, they all recognized the importance of education in terms of financial security, decision making, and confidence. They also deemed education important in a disaster context, relating it with the disaster perception and the attitude towards natural hazard occurrences. One woman in her late 40s said:

"The girls who are educated are completely different from us. They have confidence and the skill to manage emotions in the time of trouble. Their decision power is also better, which helps them be less vulnerable."

However, there are several issues that women pointed out that create hindrances for them, such as language barrier, male trainers, unified training sessions, etc. Mostly married women were more critical of this arrangement as the young girls lacked experiences of pregnancy, childbirth, postnatal complications, and other issues. A married woman in her early thirties explained it in detail. She had a graduation degree but was not employed.

"The trainings do not have any segment on women. There is no discussion about what to do if a woman is pregnant or sick. Two to three weeks before the flood, a team from Aga Khan Health Service came here and took data regarding the pregnancies or sickness or inabilities, elders. They said that in case of an 
emergency, we will evacuate you. People rely on external help a lot now. When there is a landslide or flood, teams come and collect data and take pictures. The community then waits for them to do something regarding this. They say that if they have collected the data and taken pictures, they will do something about it."

During regular time, there was significant women representation and participation on a communal level, but disaster planning lacked women's presence and also did not cater to women's needs exclusively. A notable community member admitted that the disaster plans they made on the community level regarded the household as a unit and all people as equal. Even though there were some general clauses that recognized women, children, and the elderly as more vulnerable, there was not any separate section on women's specific vulnerabilities. One of the male notables of the Hassanabad community said:

"When we plan, we plan as a community, we do not plan separately for women or do not discuss women related issues separately. I know there are many areas where women need more attention to decrease their vulnerability. Maybe the women did some discussion and planning for themselves separately and did not share with us, but otherwise, we did not cater to any women-specific needs in our plan. I feel like it was our mistake."

In Hassanabad, the women have a local and informal village-level set up called Tanzeem. It is a women-based organization which provides women with a an opportunity to own a savings account from their personal income. It is one of the most common and widely used women's social network. It is headed by a president and has a financial secretary or treasurer who keeps records for all the accounts. During the Shishper flood, women who were part of the Tanzeem discussed the looming threat among themselves. One of the members said:

"We discuss the natural hazard among ourselves. We offer to help transport people's possessions from one place to another or provide first aid to someone in case of a casualty. We have been trained to give first aid. The majority of the community members are trained, including women, to do bandages and CPR. We were also taught to make use of the available local resources for treatment if there is no first aid kit available at the spot, e.g., use chaddar [a garment women use to cover themselves] as bandages."

Unfortunately, Tanzeem is not recognised as a viable platform by the formal institutions to address women's disaster related vulnerabilities and issues.

Through this above account, it is clear that although women are not very visible on government level formal institutions but on the communal and grass-root level, the presence of women is quite strong. The adaptive capacity, resilience, and knowledge that women in Hassanabad gained through experience is often times overlooked by their male counterparts and the governmental authorities who work towards disaster mitigation. Women who are left out suffer more during the disasters as they lack resources and sometimes the confidence to act upon their intrinsic knowledge. In Hassanabad, the women underestimated their skills and strength and multiple time and quoted multiple times that they cannot function without men during a crisis. The community capacity building programmes must be gender-sensitive, as this can create a difference between life and death. Moreover, the involvement of both men and women in disaster planning and mitigation can considerably reduce the impacts of natural hazards on the communities [44].

\subsection{Women Mobility, Safety, and Vulnerability}

Ferdous and Mallick (2019) talked about the discriminatory cultural norms and practices such as lack of property ownership, lack of education, early marriage, the dowry system, and acceptance of domestic violence against women, which shape gendered vulnerability and make women more vulnerable in the disaster situation [45]. These norms and values are often based on different risk perceptions. Women's mobility and economic empowerment are also incapacitated by these discriminatory social norms. In the Shishper 
flood scenario, the discussion regarding women's mobility before and after the disaster situation was quite interesting. Typically, women's mobility within Hassanabad or nearby village settlements is neither restricted nor monitored. They do not observe any strict purdah (in the strict interpretation of Islamic law, the women observe a veil covering their faces. They do not show their faces to men outside their immediate families), albeit they are modestly dressed. The communication between the men and women of the same village is often times smooth and non-problematic as people share a mutual trust and comfort among themselves. Before the Shishper flood, a few families moved from Hassanabad to Aliabad, mostly because of the flood. However, there was one family which did not move solely because of the flood. The women lived in Hassanabad with her children. Her husband had migrated to a city downstream. She said:

"There are six houses in my neighbourhood. Before the flood, people evacuated their houses and moved to Aliabad. We also moved but not only because of the threat of flood. There were some non-local people building a slaughterhouse nearby. I used to be alone in the house after my children went to school. My family felt unsafe and therefore we decided to move."

They shifted back to their own house after the non-local labors went back.

The mobility pattern of women in Hassanabad is changing quite rapidly, especially because women are actively participating in education and economic sectors. Women from Hunza Valley have also travelled abroad for education, sports, and job purposes. The Mukhi of Hassanabad said

"Women in Hunza have a lot of freedom to move about for work and education. The families know about the detail of their travel, but it is not necessary for them to be accompanied by a male member. Women here drive as well without any restriction now. They are free to move forward in life. Women also go abroad, and their families, brothers and fathers support them. We want to see them progress."

The above statement depicts the status of women in the rural society. However, when the discussion was framed in a disaster situation, another narrative represented the underlying societal boundaries that dictate women's behavior and choices. The same Mukhi said:

"In case of danger, a man can take refugee with the nearby army camp or with police, but a woman cannot do this. She will go not to a 'ghair mehram' (a stranger man) for help, even if she has to lose her life. She will not prefer to ask help from a stranger. This is another instance where women are more vulnerable. Of course, this mindset that a woman's honor is more valuable than her life is propagated by men. They create these norms and narratives in society. "

The contradiction in the positioning of women in society showed the complexity of the relational and situational context of women and patriarchy. Women in Hassanabad did not entirely agree with this arrangement. A woman in her late 50s said that:

"We are all human beings first, and one must put humanity first. All the security departments, be it army or police, they are here for us. They have respect for us. They are here to protect us like their own sisters and mothers. We should also treat them with respect as we treat our fathers and brothers."

Counter arguing the position of women and their notion of honour, the Mukhi added:

"I am personally not in favour of 'purdah' - why should the women do purdah? Men should respect them and in a way that there is no need for any purdah (in the form of burqa). But as men, we are always scared for our sisters and daughters. Whenever my daughter travels alone, I worry about her safety. She might feel that her father does not trust her or she is weak. So if you analyze I am propagating a mindset. If, instead of this, we give them the confidence to go ahead and not worry about anything going wrong, that would be better. I am also part of the problem here." 
Here the word purdah is used quite loosely, mostly meaning avoiding unnecessary interaction with men and random visits to market places or other villages alone. The shift of the right and wrong and the scale of permissible and non-permissible during a disaster situation is incredible. The societal parameters of judgement for women switch, and men encourage women to take all the possible actions that might save their lives during a disaster. Saad (2009) also stated that during a crisis and immediately after that, the gender difference tends to temporarily disappear; however, once the situation settles, women suffer greater consequences as they lose their privacy and income opportunities [46]. One of the respondent men said:

"Purdah is not valid in the time of disaster. For example, if there is a flood and people are suffering at a community level, then police, army, or other volunteers are there to help. The helpers also do not care whether it is a man, woman, or elder that they are helping. That is why nobody thinks anything negative in these troubling situations."

Similarly, the females usually do not prefer to engage in conversation with men who are strangers, but during the crisis situation, the social norms suspend (for the time being). The male respondents believed that during disaster situations, women became "fearless" and asked for/took help from any available source, especially the young girls. The Captain of the Community Emergency Response Team (CERT) said:

"In normal times, women do not talk to strangers. But the other day, when the District Assistant Commissioner came in a disaster preparedness meeting, the young girls had a discussion with him which they would not have in a normal situation."

The women of Hassanabad, especially the housewives disagreed with this narrative. They said that the hesitation women feel does not automatically disappear in crisis situation. The trainings that women and men of Hassanabad get in the Jammat Khana and the community meetings do not explicitly address that women have mobility and communication barriers in a normal situation, which can cause an increase in women's vulnerability during disaster situations. The village Mukhi shared a broader perspective related to women's safety, honour and vulnerability during disaster situations.

"If any woman does not ask for help in desperate times, I feel that the fault is at both ends. Although she should leave no stone unturned to save her life as a society, it is also our fault. We have created and propagated a negative mindset around female honour. Even during our disaster planning phase, we have never considered certain concepts in our society that might be harmful to women, and we should actively address them. Never in a meeting have we declared that everyone should seek help if their life is in danger regardless of who is providing help."

The in-depth interviews with men of Hassanabad from different age groups brought the discussion around to these sensitive social and religious topics. The male respondents admitted that during disaster planning and mitigation, women are not given due consideration as a separate vulnerable group. During the discussion, our male respondents referred to women as their equals who are sometimes prejudiced against as a customary practice. Moreover, they implied that women are not discriminated against consciously, but rather the cultural practices are being replicated by the men and women of the community.

\section{Conclusions}

The analysis of the gendered vulnerabilities of the Hassanabad community in the context of the Shishper glacial lake outburst flood event brought to light several interesting insights related to societal structure with cultural and religious connotations. The results revealed that the Hunza Valley is undergoing a socio-economic and cultural transformation regarding women's education and empowerment. Throughout the fieldwork and analysis, 
one could clearly see the contextual links between gender and disaster. The results revealed that the perception of men and women regarding women's positionality, functionality and responsibility during disaster situations was layered and complex. While there is a willingness of women to proactively participate in the disaster management and mitigation process, there are several social and psychological barriers that hinder the involvement of women in disaster sphere. The claim of a previous study that Hunza enjoy a gender egalitarian relationship also proves to be false, as women openly claimed to be more vulnerable due to excessive responsibility of house chores, family care and land and cattle look after. The young generation of women in Hassanabad was educated, intelligent, and outspoken, whereas men were also found to be generally supportive of women's rights and empowerment. However, the men often considered very superficial factors and were less indulgent into debates that probe into gender inequalities and vulnerabilities on a deeper level especially in disaster situations. The patriarchy in the societal structure has passed along through generations which are still being practiced today.

The participation of women in the economic sphere is one of the strongest evidences of the beginning of a societal transformation in Hassanabad. This change has also brought a gradual shift of the status of women from unpaid laborers and caregivers to stakeholders. The expertise of women in different societal sectors shows that they are capable of managing any intervention in an effective and efficient manner. This change of women's status is more prominent on the household and communal level. Unfortunately, formal institutions such as government offices have yet to recognize the importance of gender inclusion in their policies and programs especially in the context of disaster management. The womenspecific and women-centric initiatives and strategies on the organizational and policy level will not substantially put a dent in the women related vulnerabilities. Moreover, such programs to empower women will utilize the intrinsic understanding of local resources and traditional indigenous knowledge to decrease the vulnerability of households and overall communities. In this study, the relationship between women and institutional hierarchy shows that there is a lack of proper public participation or meaningful "bottomup" practice. Attending to such gaps requires little effort and could bring about long term results in vulnerability reduction and sustainable community development.

Author Contributions: Conceptualization, Z.K. and A.K.; methodology, Z.K.; validation, Z.K., X.M.M. and A.K.; formal analysis, Z.K.; investigation, Z.K.; writing—original draft preparation, Z.K.; writing-review and editing, X.-M.M. and A.K.; visualization, Z.K.; supervision, X.-M.M.; funding acquisition, X.-M.M. All authors have read and agreed to the published version of the manuscript.

Funding: This study was supported by National Key Research and Development Program of China (Grant No. 2017YFC1501005), Science and Technology Major Project of Gansu Province (Grant Nos. 19ZD2FA002), National Natural Science Foundation of China (Grant No. 41661144046), and the Fundamental Research Funds for the Central Universities (Grant No. lzujbky-2019-28, lzujbky-2018k14).

Institutional Review Board Statement: Not applicable.

Informed Consent Statement: Informed consent was obtained from all subjects involved in the study. Data Availability Statement: Not applicable.

Conflicts of Interest: The authors declare no conflict of interest. The founding sponsors had no role in the design of the study; in the collection, analyses, or interpretation of data; in the writing of the manuscript, and in the decision to publish the results.

\section{References}

1. Anderson, C.L. Gendered dimensions of disaster risk management, natural resource management, and climate change adaptation in the Pacific. SPC Women Fish. Inf. Bull. 2009, 20, 3-9.

2. Mata-Lima, H.; Alvino-Borba, A.; Pinheiro, A.; Mata-Lima, A.; Almeida, J.A. Impacts of natural disasters on environmental and socio-economic systems: What makes the difference? Ambient. Soc. 2013, 16, 45-64. [CrossRef]

3. Shi, P. Disaster Risk Science, 2nd ed.; Beijing Normal University Press; Springer Nature: Singapore, 2019. Available online: https:/ /link.springer.com/book/10.1007\%2F978-981-13-6689-5 (accessed on 6 August 2021). 
4. Lavell, A.; Oppenheimer, M.; Diop, C.; Hess, J.; Lempert, R.; Li, J.; Muir-Wood, R.; Myeong, S.; Moser, S.; Takeuchi, K.; et al. Climate change: New dimensions in disaster risk, exposure, vulnerability, and resilience. In Managing the Risks of Extreme Events and Disasters to Advance Climate Change Adaptation: Special Report of the Intergovernmental Panel on Climate Change; Cambridge University Press: Cambridge, UK; New York, NY, USA, 2012; pp. 25-64. [CrossRef]

5. Hamidazada, M.; Cruz, A.M.; Yokomatsu, M. Vulnerability Factors of Afghan Rural Women to Disasters. Int. J. Disaster Risk Sci. 2019, 10, 573-590. [CrossRef]

6. $\quad$ IPCC. Climate Change 2007: Impacts, Adaptation and Vulnerability. Contribution of Working Group II to the Fourth Assessment Report of the Intergovernmental Panel on Climate Change; Parry, M.L., Canziani, O.F., Palutikof, J.P., van der Linden, P.J., Hanson, C.E., Eds.; Cambridge University Press: Cambridge, UK, 2007. [CrossRef]

7. World Economic Forum. Global Gender Gap Report 2020: Insight Report. 2019. Available online: http://www3.weforum.org/docs/ WEF_GGGR_2020.pdf (accessed on 13 January 2021).

8. Ur Rehman, M.; Zhang, Y.; Meng, X.; Su, X.; Catani, F.; Rehman, G.; Yue, D.; Khalid, Z.; Ahmad, S.; Ahmad, I. Analysis of landslide movements using interferometric synthetic aperture radar: A case study in Hunza-Nagar Valley, Pakistan. Remote Sens. 2020, 12, 2054. [CrossRef]

9. Ali, A. Indus Basin Floods: Mechanisms, Impacts, and Management; Asian Development Bank: Mandaluyong City, Philippines, 2013. [CrossRef]

10. Abbasi, S.S.; Anwar, M.Z.; Habib, N.; Khan, Q.; Waqar, K. Identifying gender vulnerabilities in context of climate change in Indus basin. Environ. Dev. 2019, 31, 34-42. [CrossRef]

11. Jost, C.; Kyazze, F.; Naab, J.; Neelormi, S.; Kinyangi, J.; Zougmore, R.; Aggarwal, P.; Bhatta, G.; Chaudhury, M.; Tapio-Bistrom, M.L.; et al. Understanding gender dimensions of agriculture and climate change in smallholder farming communities. Clim. Dev. 2015, 8, 133-144. [CrossRef]

12. Nibanupudi, H.K.; Khadka, M. Gender and Disaster Resilience in the Hindu Kush Himalayan Region. In Mountain Hazards and Disaster Risk Reduction; Springer: Tokyo, Japan, 2015; pp. 233-249. [CrossRef]

13. Rajesh, S.; Jain, S.; Sharma, P.; Bhahuguna, R. Assessment of inherent vulnerability of rural communities to environmental hazards in kimsar region of Uttarakhand, India. Environ. Dev. 2014, 12, 16-36. [CrossRef]

14. Ali, Z.S. Visual representation of gender in flood coverage of Pakistani print media. Weather Clim. Extrem. 2014, 4, 35-49. [CrossRef]

15. Ruszczyk, H.A.; Upadhyay, B.K.; Kwong, Y.M.; Khanal, O.; Bracken, L.J.; Pandit, S.; Bastola, R. Empowering women through participatory action research in community-based disaster risk reduction efforts. Int. J. Disaster Risk Reduct. 2020, 51 , 101763. [CrossRef]

16. Moreno, J.; Shaw, D. Women's empowerment following disaster: A longitudinal study of social change. Nat. Hazards 2018, 92, 205-224. [CrossRef]

17. Luqman, M.; Shahbaz, B.; Khan, I.A.; Safdar, U. Training need assessment of rural women in livestock management-Case of Southern Punjab, Pakistan. J. Agric. Res. 2013, 51, 99-108.

18. Majeed, U.; Rashid, I. Evaluating glacier surges in Karakoram region using earth observation data. Data Brief 2020, $30,105394$. [CrossRef] [PubMed]

19. Shah, A.; Ali, K.; Nizami, S.M.; Jan, I.U.; Hussain, I.; Begum, F. Risk assessment of shishper glacier, hassanabad hunza, north pakistan. J. Himal. Earth Sci. 2019, 52,1-11.

20. Gioli, G.; Khan, T.; Scheffran, J. Climatic and environmental change in the Karakoram: Making sense of community perceptions and adaptation strategies. Reg. Environ. Chang. 2014, 14, 1151-1162. [CrossRef]

21. Gioli, G.; Khan, T.; Bisht, S.; Scheffran, J. Migration as an adaptation strategy and its gendered implications: A case study from the upper Indus Basin. Mt. Res. Dev. 2014, 34, 255-265. [CrossRef]

22. Proudley, M. Fire, families and decisions. Aust. J. Emerg. Manag. 2008, 23, 37-43.

23. Hung, L.S. Gender, Intra-Household Dynamics, and Household Hurricane Preparedness: An Exploratory Study Employing a Dyadic Interview Approach. Int. J. Disaster Risk Sci. 2018, 9, 16-27. [CrossRef]

24. McDaniel, A.E. Measuring Gender Egalitarianism: The Attitudinal Difference Between Men and Women. Int. J. Sociol. 2008, 38, 58-80. [CrossRef]

25. Mulilis, J.-P. Gender and earthquake preparedness. A research study of gender issues in disaster management: Differences in earthquake preparedness due to traditional. Aust. J. Emerg. Manag. 1998, 99, 41-50.

26. Khan, A.A.; Rana, I.A.; Nawaz, A. Gender-based approach for assessing risk perception in a multi-hazard environment: A study of high schools of Gilgit, Pakistan. Int. J. Disaster Risk Reduct. 2020, 44, 101427. [CrossRef]

27. Rana, I.A.; Routray, J.K. Actual vis-à-vis perceived risk of flood prone urban communities in Pakistan. Int. J. Disaster Risk Reduct. 2016, 19, 366-378. [CrossRef]

28. Wachinger, G.; Renn, O. Risk Perception of Natural Hazards; WP3-Report; CapHaz-Net Consortium: Stuttgart, Gemany, 2010; pp. 1-111. Available online: http:/ / caphaz-net.org/outcomes-results/CapHaz-Net_WP3_Risk-Perception2.pdf (accessed on 15 May 2020).

29. Lindell, M.K.; Hwang, S.N. Households' perceived personal risk and responses in a multihazard environment. Risk Anal. 2008, 28, 539-556. [CrossRef] [PubMed] 
30. Chmutina, K.; Meding, J.V.; Bosher, L. Language Matters: Dangers of the "Natural Disaster" Misnomer. In Contributing Paper to Global Assessment Report Disaster Risk Reduction; UN Office for Disaster Risk Reduction (UNDRR): Geneva, Switzerland, 2019; pp. 1-22. Available online: https://www.preventionweb.net/files/65974_f410finalkseniachmutinalanguagematt.pdf (accessed on 12 May 2020).

31. ILO. Crises, Women and other Gender Concerns; ILO: Geneva, Switzerland, 2002.

32. Williams, S.; Mwau, A.; Seed, J. The Oxfam Gender Training Manual; Oxfam GB: Oxford, UK, 1994. Available online: https: / / policy-practice.oxfam.org/resources/the-oxfam-gender-training-manual-141359/ (accessed on 15 October 2020).

33. Nikkhah, H.A.; Redzuan, M.; Abu-Samah, A. Development of "power within" among the women: A road to empowerment. Asian Soc. Sci. 2012, 8, 39-46. [CrossRef]

34. Rowlands, J. Questioning Empowerment: Working With Women in Honduras; Oxfam GB: Oxford, UK, 1997; p. 196. Available online: http:/ / books.google.co.uk/books?id=fXJKq2JQtyoC (accessed on 5 September 2020).

35. Bradshaw, S.; Fordham, M. Women, Girls and Disasters; GSDRC: Canberra, Australia, 2013; pp. 1-54. Available online: https: //www.gov.uk/government/uploads/system/uploads/attachment_data/file/236656/women-girls-disasters.pdf. (accessed on 13 September 2020).

36. Crate, S.A. Climate and culture: Anthropology in the era of contemporary climate change. Annu. Rev. Anthropol. 2011, 40, 175-194. [CrossRef]

37. Ikeda, K. Gender Differences in Human Loss and Vulnerability in Natural Disasters: A Case Study from Bangladesh. Indian J. Gend. Stud. 1995, 2, 171-193. [CrossRef]

38. Marshall, C.; Anderson, G.L. Rethinking the public and private spheres: Feminist and cultural studies perspectives on the politics of education1. J. Educ. Policy 1994, 9, 169-182. [CrossRef]

39. Fothergill, A.; Squier, E. Women and Children in the 2015 Earthquake in Nepal. In Living Under the Threat of Earthquakes; Kruhl, J.H., Adhikari, R., Dorka, U.E., Eds.; Springer Natural Hazards: Cham, Switzerland, 2018; pp. 253-271. [CrossRef]

40. United Nations. Achieving Gender Equality, Women's Empowerment and Strengthening Development Cooperation; United Nations Publication: New York, NY, USA, 2010.

41. Dankelman, I.; Alam, K.; Ahmed, W.B.; Gueye, Y.D.; Fatema, N.; Mensah-Kutin, R. Gender, Climate Change and Human Security Lessons from Bangladesh, Ghana and Senegal Prepared for ELIAMEP. Sustain. Dev. 2008, 50, 1-73. [CrossRef]

42. Hung, L.S. Married couples' decision-making about household natural hazard preparedness: A case study of hurricane hazards in Sarasota County, Florida. Nat. Hazards 2017, 87, 1057-1081. [CrossRef]

43. Raschky, P.A. Institutions and the losses from natural disasters. Nat. Hazards Earth Syst. Sci. 2008, 8, 627-634. [CrossRef]

44. Mehta, M. Gender Matters: Lessons for Disaster Risk Reduction in South Asia; Eriksson, M.G., Rana, G.M., Murray, A.B., Mendez, J.M., Maharjan, D.R., Eds.; International Centre for Integrated Mountain Development: Kathmandu, Nepal, 2007. Available online: https:/ / www.preventionweb.net/files/2406_GenderandDisasters.pdf (accessed on 30 November 2020).

45. Ferdous, J.; Mallick, D. Norms, practices, and gendered vulnerabilities in the lower Teesta basin, Bangladesh. Environ. Dev. 2019, 31, 88-96. [CrossRef]

46. Saad, S.G. Environmental Management and Disaster Mitigation:Middle Eastern Gender Perspective. In Women, Gender and Disaster: Global Issues and Initiatives; Enarson, E., Chakrabarti, P.G.D., Eds.; SAGE Publications Inc.: Thousand Oaks, CA, USA, 2009. 